holders' freedom to act for the good of the corporation. Furthermore, the policy of granting relief only upon proof that the stock was issued below value is in accord with the general doctrine that the corporation should receive full value for any shares which it issues.

\title{
PRIVILEGED COMMUNICATIONS UNDER RULE 26(b): CONFLICT OF LAWS IN DIVERSITY CASES
}

The scope of examination in taking a deposition permitted by Rule 26(b) of the Federal Rules of Civil Procedure is limited to matters "not privileged."1 Where a deposition is being taken in one state for use in an action based on diversity of citizenship pending in a federal district court sitting in another state, ${ }^{2}$ and the witness claims a privilege recognized under the laws of only one of the two states, the United States District Court for the district in which the deposition is being taken is faced with a unique problem of conflict of laws. ${ }^{3}$ It will be the purpose of this comment to suggest a method of analysis by which the courts may best approach the choice-of-law problem presented by the twostate deposition situation in the light of the law of state-created privileges in the federal courts and of the proper weight to be given the requirements of Erie $R$. Co. v. Tompkins.4

The problem may be raised in either of two situations which ultimately must

1 "Unless otherwise ordered by the court as provided by Rule 30(b) [providing for special limitations on the scope of examination, time, place, or manner of taking the deposition, the preservation of secrecy in certain cases, and such orders as may be required in the interests of justice] or (d) [providing relief from unreasonably oppressive, embarrassing, or annoying examination], the deponent may be examined regarding any matter, not privileged, which is relevant to the subject matter involved in the pending action. ..." Fed. Rules Civ. Proc. 26(b).

2 A party to an action pending in a federal district court may, upon proper notice, as provided in Rules $30(a)$ or 31 (a), take the deposition of a witness found or residing in any state. Upon a showing that an action is pending and that the requisite notice has been given, the clerk of the district court for the district in which the deposition is to be taken must issue a subpoena compelling the witness to give his deposition, and the subpoena may require the production of documents. Rule 45(d). If the witness refuses to answer a question, the party proponent may move the court in the district where the deposition is being taken for an order compelling the witness to answer. Rule 37(a). At the hearing on this motion, the witness has an opportunity to justify his refusal, perhaps by making a claim of privilege.

3 The question could come before the court in one of several ways: a motion to quash or restrict the scope of the subpoena, a petition to suppress a deposition already taken, a motion by the party proponent for an order compelling the witness to answer under Rule 37 , or a motion by the proponent for an order citing the witness for contempt. Consult note 2 supra. For examples consult Palmer v. Fisher, 228 F. 2d 603 (C.A. 7th, 1955), discussed in text at p. 705 infra (motion by witness to suppress; cross motion by proponent for contempt citation); Ex parte Sparrow, 14 F.R.D. 351 (N.D. Ala., 1953), discussed in text at p. 706 infra (motion for compelling order under Rule 37). A motion to limit the scope of examination must be made to the court in which the action is pending. Rule $30(\mathrm{~b})$. The trial court might also be faced with the question if objection is made to the introduction in evidence of a deposition containing privileged matter.

4304 U.S. 64 (1938). 
be analyzed separately: (a) the testimony sought is privileged only under the law ${ }^{5}$ of the state where the deposition is to be taken or (b) only by the law of the state where the trial is to be held. In either instance the district judge, before determining the validity of the claim of privilege, must decide whether the privilege law of the deposition state, the trial state, or some "general law" of the federal courts is to govern. Further, if the choice is narrowed to the competing bodies of state law, it must be decided whether the conflict-of-laws rules of the state in which the court sits or some general principles of conflict of laws are to govern the choice.

To date only two cases raising these problems have been reported, both involving privileges not traditionally recognized at common law but created by state statutes. In each, the privilege of the deposition state was applied. In Palmer v. Fisher, ${ }^{6}$ the United States District Court for the Northern District of Illinois issued a subpoena duces tecum directing an employee of an Illinois accounting firm to give his deposition for use in a diversity action pending in Florida. The deponent claimed privilege under an Illinois statute, ${ }^{7}$ and was upheld by the district court. On appeal, the Seventh Circuit noted that "[f]ederal courts have held that state laws creating a privilege are substantive, and they have followed them in diversity cases,"8 and held that state law should apply, notwithstanding a contrary federal common-law rule. ${ }^{9}$ On the question of which state law should apply, the court, apparently assuming that Florida would not recognize as privileged information obtained professionally by a public accountant, ${ }^{10}$ held it proper, nevertheless, to apply the Illinois statute: "[I]f any court, state or federal, sitting in Illinois should require an accountant to testify as to such information [the public policy of Illinois would be defeated] ... whether the testimony was to be used in a court sitting in Illinois or in any other state."11 Although resting primarily on this policy consideration, the court appeared to draw additional support from the general rule that questions of evidence, in-

5 "Law" here includes statutes with their interpretive decisions, and rules of common law created by the courts of the state.

228 F. 2 d 603 (C.A. 7th, 1955).

7 Ill. Rev. Stat. (1955) c. $110 \frac{1}{2}, \S 51$ : "A public accountant shall not be required by any court to divulge information or evidence which has been obtained by him in his confidential capacity as a public accountant."

${ }^{8}$ Palmer v. Fisher, 228 F. 2d 603, 608 (C.A. 7th, 1955). Consult discussion of the problem of characterizing privilege as "substantive" or "procedural" for purposes of the Erie doctrine at pp. 709-10 infra. It is unclear whether the court meant to imply that the Erie case governed the result.

' Himmelfarb v. United States, 175 F. 2d 924 (C.A. 9th, 1949). In a prosecution for attempted income tax evasion, the court, holding that the presence of an accountant at a conference between defendant and his attorney removed the attorney-client privilege from communications made at the conference, stated that communications to an accountant are not privileged.

${ }^{10}$ In fact, Florida has a statute similar to that in force in Illinois. Fla. Stat. (1955) $\S 473.15$.

11 Palmer v. Fisher, 228 F. 2d 603, 608 (C.A. 7th, 1955). 
cluding privilege, are generally decided by the law of the forum, ${ }^{12}$ reasoning that "[s]ince the proceeding to suppress a deposition is an independent action, the law of the forum is the law of Illinois."13

In $E x$ parte Sparrow ${ }^{14}$ a newspaper employee giving his deposition in Alabama refused to disclose the sources of information published in the newspaper for which he was employed, claiming privilege under an Alabama statute..$^{15} \mathrm{It}$ was conceded that in New York, where the diversity action was pending, such a privilege for newsmen was denied. The United States District Court for the Northern District of Alabama held that in the absence of a federal rule denying the privilege, state law should govern, but said that the doctrine of Erie R. Co. v. Tompkins did not compel the result since a question of privilege is not "substantive" within the meaning of the Erie rule..$^{16}$ As to the conflict between the Alabama and New York rules, the court in favoring the Alabama statute purported to follow the general doctrine that the law of the forum governs questions of procedure, reasoning that "[f]or purposes of determining the witness' claim of privilege, this court, by Rule 37, is constituted the forum or the place where plaintiff, the proponent, is required to pursue his remedy to compel the witness to answer."17

12 Consult Rest., Conflict of Laws $\S 597$ (1934); 3 Beale, Conflict of Laws 1613-14 (1935). The rule is part of the doctrine that while the law of the place of the transaction governs substantive rights, matters of procedure-relating only to the remedy-are governed by the law of the forum. Rest., Conflict of Laws $\$ 585$ (1934); Stumberg, Principles of Conflict of Laws 134 (2d ed., 1951); 3 Beale, op. cit. supra, at 1600; Goodrich, Conflict of Laws 157-9 (1927). The general doctrine is said to be based on a balancing of the rights of the parties arising under foreign law against the practical convenience of the local court in administering justice, a preponderance of the latter resulting in characterization of a rule as "procedural." Stumberg, op. cit. supra, at 134 n. 1; 3 Beale, op. cit. supra, at 1601; Cook, "Substance" and "Procedure" in the Conflict of Laws, 42 Yale L.J. 333 (1933). But consult Goodrich, op. cit. supra.

"Substance" and "procedure" take on a different meaning when used to determine the applicability of the rule in Erie R. Co. v. Tompkins, 304 U.S. 64 (1938). For a careful analysis and a distinction between these two sets of meanings see Sampson v. Channell, 110 F. 2d 754 (C.A. 1st, 1940), cert. den. 310 U.S. 650 (1940).

13 Palmer v. Fisher, 228 F. 2d 603, 608-609 (C.A. 7th, 1955).

1414 F.R.D. 351 (N.D. Ala., 1953).

${ }^{15}$ Code of Ala. (1940) Title $7, \S 370$ : "No person engaged in, connected with or employed on any newspaper while engaged in a news gathering capacity shall be compelled to disclose, in any legal proceeding or trial, before any court or before a grand jury of any court, or before the presiding officer of any tribunal or his agent or agents, or before any committee of the legislature, or elsewhere, the source of any information procured or obtained by him and publisbed in the newspaper on which he is engaged, connected with or employed." The section was amended in 1949 to include employees of radio broadcasting and television stations. Code of Ala. (1953 Cum. Supp.) § 370 .

${ }^{16}$ Ex parte Sparrow, 14 F.R.D. 351, 353 (N.D. Ala., 1953). It is unclear whether the court's reference to a "federal rule" means a Federal Rule of Civil Procedure or a federal commonlaw rule. As to the probable effect of the former, consult discussion of Professor Moore's thesis at p. 707 infra. For the position that Rule 43(a) may authorize or require a federal commonlaw rule denying a privilege to govern in the face of a contrary state statute, consult Green, The Admissibility of Evidence Under the Federal Rules, 55 Harv. I. Rev. 197 (1941), and discussion at p. 708 infra.

${ }^{17} 14$ F.R.D. 351, 353 (N.D. Ala., 1953). 
While the local privilege statute was applied in both, the Palmer and Sparrow cases appear to differ on the extent to which the federal courts in diversity cases are compelled to apply state law in determining questions of privilege. Resolution of the issue depends not only upon the demands of the Erie doctrine, but also upon a proper interpretation of Rule 43(a) of the Federal Rules of Civil Procedure. Rule 43(a) provides for the admissibility of all evidence that would be admissible under whichever of the following most favors its reception: the statutes of the United States, the rules of evidence formerly applied by federal courts in equity cases, or the rules of evidence applied by the courts of the state in which the federal court sits. ${ }^{18}$ Although the Rule speaks in terms of admissibility rather than exclusion, it is generally agreed that it governs questions of privilege, ${ }^{19}$ both at the trial and in deposition proceedings. ${ }^{20}$ The writers do not agree, however, as to whether the Rule requires exclusion of testimony privileged under state law. In the affirmative, Professor Moore maintains that privileged communications "are controlled principally by state statutes, which under Rule 43(a) will clearly govern, if no federal statutes or rules of court contrary to the state statutes are enacted or promulgated, as the case may be, since the state

18 "In all trials the testimony of witnesses shall be taken orally in open court, unless otherwise provided by these rules. All evidence shall be admitted which is admissible under the statutes of the United States, or under the rules of evidence heretofore applied in the courts of the United States on the hearing of suits in equity, or under the rules of evidence applied in the courts of general jurisdiction of the state in which the United States court is held. In any case, the statute or rule which favors the reception of the evidence governs and the evidence shall be presented according to the most convenient method prescribed in any of the statutes or rules to which reference is herein made. The competency of a witness to testify shall be determined in like manner." Fed. Rules Civ. Proc. 43(a).

19 Consult generally 5 Moore, Federal Practice 1303-1335 (2d ed., 1951); Pugh, Rule 43(a) and the Communication Privileged Under State Law: An Analysis of Confusion, 7 Vand. L. Rev. 556 (1954); Green, Federal Civil Procedure Rule 43(a), 5 Vand. L. Rev. 560 (1952); Green, The Admissibility of Evidence Under the Federal Rules, 55 Harv. L. Rev. 197 (1941).

Before the promulgation of the Rules it had been settled that the Rules of Decision Act, 1 Stat. 92 (1789), as amended 62 Stat. 944 (1948), 28 U.S.C.A. $\$ 1652$ (1950) (consult note 23 infra), required federal courts in suits at common law to follow state privilege statutes unless the Constitution, treaties or statutes of the United States otherwise provided. Connecticut Life Ins. Co. v. Union Trust Co., 112 U.S. 250 (1884). Compare Mutual Ben. Life Ins. Co. v. Robison, 58 Fed. 723 (C.C.A. 7th, 1893) where the court relied both on the Connecticut Life case and on Rev. Stat. $\delta 858$ (the so-called Competency of Witnesses Act), repealed in 1948, 62 Stat. 993 (1948), 28 U.S.C.A. $\$ 631$ (1952), which provided that "[ $t]$ he laws of the state in which the court is held shall be the rules of decision as to the competency of witnesses in the courts of the United States in trials at common law, and in equity and admiralty." Competency of witnesses is now governed by Fed. Rules Civ. Proc. 43(a), set out in note 18 supra.

Where there was no state statute in point, the cases were in conflict over whether or not the federal court was bound to follow state judicial decisions on admissibility of evidence; the typical approach was to decide such questions on the basis of general federal common law. This was in accord with the rule of Swift v. Tyson, 16 Pet. (U.S.) 1 (1842), that the Rules of Decision Act required conformity only with state statutes and not with state common-law rules. Consult 5 Moore, Federal Practice 1308, 1309 (2d ed., 1951).

${ }^{20}$ Wild v. Payson, 7 F.R.D. 495 (S.D. N.Y., 1946). Consult 4 Moore, op. cit. supra note 19, at 1084-5; Pugh, Rule 43(a) and the Communication Privileged Under State Law: An Analysis of Confusion, 7 Vand. I. Rev. 556, 564 et seq. (1954). 
statutes were followed under the federal equity practice."21 Professor Green, on the other hand, has questioned Moore's premise, and suggested that Rule 43(a) be read to require following state law if it denies a privilege, but not if it grants one. ${ }^{22}$ In choosing between these two interpretations, two aspects of the rule in Erie R. Co. v. Tompkins are relevant.

The principal effect of the Erie doctrine has been to elevate, in diversity cases, state judicial precedents in "substantive" matters, i.e., matters substantially affecting the outcome of a case, to the dignity formerly accorded state statutes under the interpretation of the Rules of Decision Act ${ }^{23}$ propounded in Swift $v$. Tyson ${ }^{24}$ Although it was only necessary for the decision in the Erie case to hold that "laws" as used in the Act ${ }^{25}$ meant, in diversity cases, the common-law rules applied by the state courts as well as "positive statutes of the state,"26 the Court

${ }^{21} 5$ Moore, op. cit. supra note 19, at 1332-1333. No mention is made of privileges accorded by the state common law. In another place, Professor Moore maintains that the federal courts are not bound by Rule 43(a) or the Erie decision to follow state decisions interpreting the scope of state statutory privileges. 4 Moore, op. cit. supra, at 1152. Consult text at pp. 709-10 infra.

${ }_{22}$ Consult Green, The Admissibility of Evidence Under the Federal Rules, 55 Harv. L. Rev. 197, 208-209 (1941).

${ }^{23} 1$ Stat. 92 (1789), as amended 62 Stat. 944 (1948), 28 U.S.C.A. $\$ 1652$ (1950). The original statute, Section 34 of the Judiciary Act of 1789, 1 Stat. 73, 92 (1789), has been amended to read: "The laws of the several states, except where the Constitution or treaties of the United States or Acts of Congress otherwise require or provide, shall be regarded as rules of decision in civil actions in the courts of the United States, in cases where they apply." (Italics added.) In the original version, "actions at common law" appeared in place of the emphasized language.

2416 Pet. (U.S.) 1 (1842). The Erie decision held that federal courts in diversity cases were bound to follow state decisional law as well as the "positive statutes of the state" [Swift v. Tyson, 16 Pet. (U.S.), 1, 18 (1842)]. It was said that "[t]here is no federal general common law. Congress has no power to declare substantive rules of common law applicable in a State whether they be local in their nature or "general." " Erie R. Co. v. Tompkins, 304 U.S. 64, 78 (1938). (Italics added.) In explaining the distinction between "substantive" rules, which the Erie decision held within the exclusive province of the states, and "procedural" rules, which by implication are within the power of federal courts to decide, the Court has subsequently said, per Frankfurter, J., "The question is whether such a [rule] concerns merely the manner and the means by which a right to recover, as recognized by the State, is enforced, or whether ... [it] is a matter of substance in the aspect that alone is relevant to our problem, namely, does it significantly affect the result of a litigation for a federal court to disregard a law of a State that would be controlling in an action upon the same claim by the same parties in a State court?" Guaranty Trust Co. v. York, 326 U.S. 99, 109 (1945).

It has been argued, and apparently presumed by the Court, that a state statute merely "procedural" would not be binding on the federal courts. See, e.g., Cohen v. Beneficial Loan Corp., 337 U.S. 541, 555 (1949), and dissenting opinions of Douglas and Rutledge, JJ., ibid., at $557-561$.

The precise scope of "substance" and "procedure" under the Erie rule is uncertain, but it has been said that "the federal court administers the state system of law in all except details related to its own conduct of business." Cohen v. Beneficial Ioan Corp., supra, at 555. Consult Sampson v. Channell, 110 F. 2d 754 (C.A. 1st, 1940), cert. den. 310 U.S. 650 (1940); compare the "substance-procedure" distinction for purposes of deciding applicability of the lex fori, note 12 supra.

251 Stat. 92 (1789). Consult note 23 supra.

${ }^{28}$ Swift v. Tyson, 16 Pet. (U.S.), 1, 18 (1842). Consult note 24 supra. 
went on to say, "Congress has no power to declare substantive rules of common law applicable in a State." ${ }^{\prime 27}$ The validity of an act of Congress explicitly purporting to prescribe "substantive" rules for diversity cases has not been passed upon, ${ }^{28}$ but the Court has recently reiterated in strong dictum that the constitutionality of such a statute would be subject to serious doubt..$^{29}$ If privilege is a "substantive" matter, Professor Green's interpretation of Rule 43(a), if applied to diversity actions, would squarely pose the question of whether the Erie rule is to be regarded as merely construing the Rules of Decision Act or as defining the constitutional limits of congressional power in diversity cases.

Professor Green's interpretation does not raise this constitutional question, bowever, if rules of privilege are merely "procedural," and hence not within the scope of the Erie doctrine. There are few authorities on the question. In. Ex parle Sparrow the court said that since privilege is not a substantive matter, the Erie case did not govern. ${ }^{30}$ This view is in accord with a short line of decisions in the United States District Court for the Northern District of Ohio, ${ }^{31}$ the only square holdings on this point. Questions of privilege were there held to be procedural, and the court refused to follow the state decisions on the scope of the attorney-client privilege. ${ }^{32}$ In support of the decision, one of the cases noted "the anomalous feature that certain applications of discovery process may be available ... in cases arising under the general federal jurisdiction of a district court, and may not be available in cases arising solely by reason of diversity of citizenship . . . if Erie R. Co. v. Tompkins . . . is applicable." ${ }^{233}$ The comment

${ }^{27}$ Erie R. Co. v. Tompkins, 304 U.S. 64, 78 (1938). Consult note 24 supra.

${ }^{28}$ In Ragan v. Merchants Transfer Co., 337 U.S. 530 (1949), the Court held that for purposes of deciding whether a state statute of limitations was tolled by filing the complaint or by service of process, the state statute was to govern although contrary to the Federal Rules of Civil Procedure. The constitutional question was not discussed. In Cohen v. Beneficial Loan Corp., 337 U.S. 541 (1949), the Court was careful to point out that the state statute did not conflict with the applicable Federal Rule. Ibid., at 556. For the view that a federal statute in an area generally considered procedural, but which may substantially affect the outcome of a case, can, consistently with Erie, prevail over a contrary state rule, see Sampson v. Channell, 110 F. 2d 754, 757 (C.A. 1st, 1940), cert. den. 310 U.S. 650 (1940).

${ }^{29}$ See Bernhardt v. Polygraphic Company of America, 350 U.S. 198 (1956).

${ }^{30} 14$ F.R.D. 351, 353 (N.D. Ala., 1953).

${ }^{31}$ Brookshire v. Pennsylvania R. Co., 14 F.R.D. 154 (N.D. Ohio, 1953); Scourtes v. Fred W. Albrecht Grocery Co., 15 F.R.D. 55 (N.D. Ohio, 1953); Humphries v. Pennsylvania R. Co., 14 F.R.D. 177 (N.D. Ohio, 1953); Panella v. Baltimore \& O. R. Co., 14 F.R.D. 196 (N.D. Ohio, 1951).

${ }^{32}$ But cf. Miller v. Pacific Mutual Life Ins. Co., 116 F. Supp. 365 (W.D. Mich., 1953), holding that construction of a state statute with respect to the validity of a waiver of the physician-patient privilege was a substantive question to be governed by state decisions. But in the Miller case, unlike the Ohio cases (note 31 supra), there appears to have been no federal precedent holding contra to the state rule.

It is not significant that the Sparrow case involved a state statute while the Ohio cases and the Miller case dealt with judicial decisions. A state rule, statutory or judicial, if "substantive" must be followed under the Erie rule.

${ }^{33}$ Humphries v. Pennsylvania R. Co., 14 F.R.D. 177, 180 (N.D. Ohio, 1953), quoting Reeves v. Pennsylvania R. Co., 8 F.R.D. 616, 619 (D. Del., 1949). 
is equally pertinent with respect to a claim of privilege at the trial. Unless it clearly appears that rules of privilege may substantially affect the outcome of a case ${ }^{34}$ no constitutional limitation should be placed upon the policy of the Federal Rules to liberalize procedures for developing the facts of a legal controversy by holding privilege to be "substantive," and thus within the scope of Erie.

Professor Green's interpretation of Rule 43(a) is, therefore, probably not precluded by the Constitution, and it would appear to advance the policy of freer admissibility evidenced by the Rule. ${ }^{35}$ Moore's construction, however, in following state privilege statutes, avoids constitutional questions altogether, ${ }^{36}$ and has been adopted by the few cases which have explicitly passed upon the question of interpreting Rule 43(a). ${ }^{37}$ Moreover, while the grounds for decision differ, the cases decided before and after the promulgation of the Rules are unanimous in following state privilege statutes, ${ }^{38}$ at least in diversity cases. ${ }^{39}$

Assuming that state rather than federal law governs a claim of privilege under

${ }^{34}$ Guaranty Trust Co. v. York, 326 U.S. 99, 109 (1945). Consult note 24 supra.

${ }^{35} \mathrm{~A}$ caveat is called for. A policy of free admissibility does not require a relaxation of privileges, although both result in a fuller development of the facts of a lawsuit. The distinction between the functions of non-admissibility and non-disclosure is discussed at p. 717 infra.

${ }^{36} \mathrm{~A}$ desire to avoid deciding the constitutional questions raised by the Erie case was a deciding factor in the adoption by the Supreme Court of a construction of the National Arbitration Act, 43 Stat. 883, 9 U.S.C.A. \$§ 1-3 (1947), in Bernhardt v. Polygraphic Company of America, 350 U.S. 198 (1956).

${ }^{37}$ Berdon v. McDuff, 15 F.R.D. 29 (E.D. Mich., 1953); Rediker v. Warfield, 11 F.R.D. 125 (S.D. N.Y., 1951); Stiles v. Clifton Springs Sanitarium Co., 74 F. Supp. 907 (W.D. N.Y., 1947).

${ }^{38}$ Decision based on Rules of Decision Act or Competency of Witnesses Act: Mutual Ben. Life Ins. Co. v. Robison, 58 Fed. 723 (C.A. 7th, 1893); Connecticut Life Ins. Co. v. Union Trust Co., 112 U.S. 250 (1884). Statute followed without discucssion: Baum v. Pennsylvania R. Co., 14 F.R.D. 398 (E.D. N.Y., 1953); Leonia Amusement Corp. v.Loew's Inc., 13 F.R.D. 438 (S.D. N.Y., 1952); Engl v. Aetna Life Ins. Co., 139 F. 2d 469 (C.A. 2d, 1943); Aetna Life Ins. Co. v. McAdoo, 106 F. 2d 618 (C.A. 8th, 1939); Thompson v. Smith, 103 F. 2d 936 (App. D.C., 1939); Southwest Metals Co. v. Gomez, 4 F. 2d 215 (C.A. 9th, 1925); Federal Mining \& Smelting Co. v. Dalo, 252 Fed. 356 (C.A. 9th, 1918); Pennsylvania R. Co. v. Durkee, 147 Fed. 99 (C.A. 2d, 1906). Statute followed after statement of rule that "the federal courts follow the law of the forum as to communications privileged by state statutes": Van Wie v. United States, $77 \mathrm{~F}$. Supp. 22 (N.D. Iowa, 1948) (action under the Federal Tort Claims Act); Munzer v. Swedish American Line, 35 F. Supp. 493 (S.D. N.Y., 1940) (diversity suit). Statute followed on grounds of a "proper" construction of Rule 43(a): Berdon v. McDuff, 15 F.R.D. 29 (E.D. Mich., 1953); Rediker v. Warfield, 11 F.R.D. 125 (S.D. N.Y., 1951); Stiles v. Clifton Springs Sanitarium Co., 74 F. Supp. 907 (W.D. N.Y., 1947).

Those cases decided prior to the promulgation of the rules which explicitly or impliedly base their decision on the Rules of Decision Act are not relevant on question of interpretation here involved. Granting that the Act requires adherence to state law "except where . . . Acts of Congress otherwise require or provide," the question at issue is whether Rule 43(a), which appears to have the force of statute [28 U.S.C.A. $\$ 2072$ (1952)], "otherwise provides."

${ }^{39}$ State privilege statutes have been held not binding in non-diversity actions. In re Albert Iindley Lee Memorial Hospital, 209 F. 2d 122 (C.A. 2d, 1953), cert. den. sub. nom. Cincotta v. United States, 347 U.S. 960 (1954). See also Fahey v. United States, 18 F.R.D. 231 (S.D. N.Y., 1955). But cf. Van Wie v. United States, 77 F. Supp. 22 (N.D. Iowa, 1948). 
the Rules, the question in the two-state deposition situation becomes one of determining which state law to apply. In making the choice, the rule of Klaxon Co. v. Slentor $\mathrm{Co}^{40}$ would appear to require the district court to follow the conflict-of-laws rule which the state court would apply in determining whether the local law of privilege or that of the trial state is to govern.

Looking to state law on this conflicts problem one finds few and conflicting authorities. With the exception of New York and Colorado, ${ }^{41}$ the state courts have not passed upon the question of the proper law to govern a claim of privilege in a proceeding to take a deposition for use out of state, ${ }^{42}$ nor has any com-

${ }^{40} 313$ U.S. 487 (1941). On certiorari to resolve a conflict between circuits, the Court approved the reasoning and result in Sampson v. Channell, 110 F. 2d 754 (C.A. 1st, 1940), supra note 24 , and held that the policy of the Erie case requires the federal courts to apply the conflict-of-laws rules prevailing in the courts of the state in which they sit. In Griffin v. MICCoach, 313 U.S. 498 (1941), the Klaxon rule was held to require adherence to a state conflicts rule which denied, as a matter of public policy, any claim by certain assignees of a life insurance policy regardless of the validity of policy or assignment under the law of the state where made. The question arose on a bill of interpleader, and the decision has been severely criticized on the grounds that the federal interpleader statute, 62 Stat. 931, 936 (1948), 28 U.S.C.A. $\$ \S 1335,1397$ (1950), provided for a result which could not be reached in the state courts by providing nationwide service of process on the adverse claimants. It has been pointed out that one of the purposes of the statute was to avoid results such as that reached in New York Life Ins. Co. v. Dunlevy, 241 U.S. 578 (1916), where the stakeholder was subjected to double liability because of his inability to get a binding judgment in a state court against a non-resident claimant who could not be served within the jurisdiction. Since an interpleader action against a non-resident claimant would not be possible in the state court, and since Congress has exhibited an intention to alter the results which would obtain in a state court, it is held illusory to insist on conformity with the results in the state courts. Consult 2 Crosskey, Politics and the Constitution in the History of the United States 931 (1953); Currie, Change of Venue and the Conflict of Laws, 22 U. of Chi. L. Rev. 405, 449 (1955).

Where the deposition state has no statute providing compulsory process for taking depositions for use out of state, Rules $26(\mathrm{~b})$ and 45 provide a remedy that would be unavailable in the state courts. Consequently, for reasons analogous to those advanced in criticism of Griffin v. McCoach, it may be urged that the Klaxon rule should not apply to the two-state deposition situation.

The Griffin case must also be taken as setting to rest what is perhaps, at best, a specious argument to the effect that because a federal statutory remedy is pursued, the proceeding involves the decision of a "federal question," and that under the rule of D'Oench, Duhme \& Co. v. F.D.I.C., 315 U.S. 447 (1942), the Klaxon rule is not applicable.

41 The conflict-of-laws question was not discussed in In re Martin, 141 Ohio St. 87, 47 N.E. 2d 388 (1943), but the decision supported the claim of local privilege, and there is language indicating accord with the New York cases. Ibid., at 103 and 395.

12 A majority of American jurisdictions have adopted statutes providing for the issuance of compulsory process to aid in taking depositions for use in a trial pending in a federal court, a court of a sister state, or of a foreign nation. Consult 8 Wigmore, Evidence 94 n. 1 (3d ed., 1940 ); ibid., at 58 (Supp., 1955). Typical requirements for such issuance are that an action be pending in the foreign jurisdiction and that there be a valid commission from the foreign court authorizing the taking of a deposition in the jurisdiction. E.g., Application of Hild, 124 N.Y.S. 2d 271 (S. Ct., 1953). With some variations, most statutes are similar to the Uniform Foreign Depositions Act, 9A Uniform Laws Ann. 39 (1951), adopted in thirteen jurisdictions, ibid., at 13 (Cum. Supp., 1955): "Whenever any mandate, writ or commission is issued out of any court of record in any other state, territory, district or foreign jurisdiction, or whenever upon notice or agreement it is required to take the testimony of a witness or witnesses in this state, witnesses may be compelled to appear and testify in the same manner and by the 
prehensive treatment of privileged communications in the conflict of laws been found among the writers. Totally unexplored is the question of the requirements of the full faith and credit and due process clauses in the situation. Moreover, the significance of both the New York and Colorado authorities is diminished by the fact that in each the choice-of-law question was that of determining which body of decisions governed on the issue of whether particular testimony was covered by a privilege recognized in both the trial and deposition states.

In New York it appears settled that the law of the deposition state governs a claim of attorney-client privilege. In a recent case, Application of Franklin Washington Trust Co. ${ }^{43}$ the deposition court said:

Respondents are attorneys in this state and the inquiry concerns professional acts done here. They should not be allowed to reveal, much less compelled to, any matter which the public policy of this state deems inviolate. The evil which is sought to be avoided is the revelation of the confidential matter per se, not the exclusion of testimony which might be in some way harmful.4s

As early as 1889 similar reasoning supported the conclusion that the law of England, where the trial was pending, was irrelevant to the validity of a New York attorney's claim of privilege at the taking of a deposition in that state. In In re Whitlock, ${ }^{45}$ the court said:

The evil of permitting this testimony to be given is instant upon its disclosure before the commissioners, when it becomes at once a matter of public record, and is not dependent, in any respect, upon the use to which it may ultimately be put on the trial of the action in which it is sought to be used. ${ }^{46}$

A view contrary to that of the lower courts of New York has been taken by the Supreme Court of Colorado. In Metropolitan Life Ins. Co. v. Kaufman, ${ }^{47}$ the question was whether the physician-patient privilege had been waived under a statute adopted in almost identical form by the trial and deposition states. The Colorado (deposition state) court held that the trial-state decisions governed,

same process and proceeding as may be employed for the purpose of taking testimony in proceedings pending in this state."

For the situation generally and under the common law, absent such statutes, consult 8 Wigmore, Evidence at 93-97 (3d ed., 1940).

43148 N.Y.S. 2d 731 (S. Ct., 1956).

"1 Ibid., at 733. Accord: In re Topliffe, 191 Misc. 466, 77 N.Y.S. 2d 716 (S. Ct., 1948), aff'd 274 App. Div. 760, 80 N.Y.S. 2d 360 (1st Dep't, 1948); In re Martin, 141 Ohio St. 87, 47 N.E. 2d 388 (1943); In re Whitlock, 51 Hun 351, 3 N.Y. Supp. 855 (S. Ct., 1889); see Ex parte Taylor, 110 Tex. 331, 220 S.W. 74 (1920). But cf. Metropolitan Life Ins. Co. v. Kaufman, 104 Colo. 13, 87 P. 2 d 758 (1939).

The court's reference to exclusion of evidence was directed to counsel's argument that the settled rule in New York is that questions of the admissibility, competency, materiality, and relevancy of evidence are to be left to the determination of the trial court. Application of Franklin Washington Trust Co., 148 N.Y.S. 2d 731, 733 (S. Ct., 1956).

451 Hun 351, 3 N.Y. Supp. 855 (S. Ct., 1889).

$48 \mathrm{Ibid}$., at $354,857$.

47 104 Colo. 13, 87 P. 2 d 758 (1939). 
saying merely, "[W]e are concerned with the law of the forum, which is that of the state of Missouri [the trial state]."48

These decisions offer a partial indication of the positions these courts would take where the privilege was wholly denied by one of the states concerned. The reasoning of the New York cases would appear to apply with equal force where a privilege was recognized only by the deposition state, although there is no indication of what the New York rule would be where the privilege is recognized only in the trial state. Conversely, the approach of the Colorado court would probably extend to recognizing a trial-state privilege wholly denied under local law, although the result where the privilege is recognized only in the deposition state is uncertain.

It would appear that despite the compulsion of the Klaxon rule, as a practical matter the paucity of state precedents will in most cases force the district judge to make an independent choice of law, even though he may purport to be deciding a question of state law. The controlling principles for decision of this conflicts question may be briefly outlined.

At the outset it should be noted that the classic rubric that the lex fori governs matters of procedure ${ }^{49}$ is not helpful. Conceding that questions of privilege may validly be characterized as procedural for purposes of the conflict of laws, the difficulty in the problem at hand is that of determining whether the court supervising the taking of the deposition or the court before which the action is to be tried is the "forum" within the meaning of the traditional rule. ${ }^{50}$ The reason given by the Seventh Circuit in the Palmer case for concluding that the deposition court is the forum, viz., that a proceeding to quash a deposition is an "independent proceeding," "61 is hardly convincing, since the proceeding had been previously characterized as "independent" in order to hold that an order suppressing a deposition was appealable. ${ }^{52}$ The decision of a conflict-of-laws question cannot properly be made to turn on the appealability of an order rendered in the proceedings. ${ }^{53}$ The approach of the Sparrow case, where the deposi1945).

${ }^{8} \mathrm{Ibid}$. , at 15 and 759. Compare Levy v. Mutual Life Ins. Co., 56 N.Y.S. 2d 32 (S. Ct.,

In the Kaufman case there were no Colorado decisions on the waiver point so it is possible to interpret the opinion as deciding a question of local law on the basis of the decisions of a state having a similar statute.

19 Consult note 12 supra.

${ }^{50}$ Where a foreign privilege is claimed at the trial of an action, the general rule is that the law of the forum governs, and the foreign privilege will not be enforced. Societe Internationale v. McGrath, 9 F.R.D. 680 (D.D.C., 1950) (privilege accorded by foreign government to official documents); Doll v. Equitable Life Assur. Soc., 138 Fed. 705 (C.A. 3d, 1905) (New York privilege claimed by New York physician in suit on a contract of insurance made in New York); 15 C.J.S. Conflict of Laws \& $22 j$ (1939).

51 Palmer v. Fisher, 228 F. 2d 603, 608-609 (C.A. 7th, 1955).

52 Ibid., at 606.

53 Indeed, the Palmer opinion indicates that primary reliance was placed by the court upon giving effect to the local public policy. Consult text at p. 705 supra. 
tion court was deemed the forum because, under Rule 37, it is there that the proponent must pursue his remedy to have the witness compelled to answer, ${ }^{54}$ is also not without difficulty. Characterizing the deposition court as the forum because it is the place where the proponent must seek enforcement of his right to take testimony by deposition calls attention to the possible fallacy of assuming that in such proceedings privilege questions are "procedural" within the meaning of the traditional rule. Where a litigant comes into court seeking to enforce a right to take testimony for use out of state, rules of privilege may be said to go to the very substance of that right. ${ }^{55}$ It would appear that any attempt to define the concepts "forum" and "procedure" and to reason deductively from such definitions to a solution of the conflict-of-privilege-law problem is doomed to failure.

A more profitable approach would appear to require an examination of the policies behind the granting of a privilege and a determination of the extent to which those policies call for an extension of the privilege to the situation at hand. Wigmore states that the creation of a communication privilege represents a determination on the part of legislature or court that the public interests to be served by protecting certain information from disclosure, for example, encouraging clients to confide freely in their attorneys, outweigh the desirability of facilitating the search for truth in any particular litigation. ${ }^{56}$ Although the absence of a particular privilege in a given jurisdiction may merely represent a failure to deal with the question, it will be assumed for purposes of analysis that a conscious resolution of the competing policies in favor of the ascertainment of truth was intended.

In broad terms, the problem is the extent to which the courts of any state are to apply that state's resolution of these conflicting policies to cases having outof-state elements. Several situations can be imagined in which the law of another state, contrary to the law of the jurisdiction called upon to determine a claim of privilege may at least arguably be relevant: (a) communicator, communicatee, or both, are residents of or do business in the other state; (b) the communication occurred in the other state; (c) the transactions establishing the confidential relation occurred in or were made with reference to the other state; (d) the trial of the case will be held in the foreign state.

Where situation (d) is not present, i.e., the court deciding the claim of privilege is the court in which the facts of the case are to be determined, the courts are probably justified in ignoring all other foreign elements and applying the

54 Ex parte Sparrow, 14 F.R.D. 351, 353 (N.D. Ala., 1953). Consult text at p. 706 supra.

${ }^{55}$ In the usual case the litigant seeks to enforce, for example, a contract right. It may then be quite proper to classify rules of privilege as procedural since they relate to the process of developing the facts necessary to establish (or defeat) the plaintiff's claim. Consult 3 Beale, Conflict of Laws 1600, 1614 (1935).

568 Wigmore, Evidence 102 et seq. (3d ed., 1940). 
law of the forum..$^{57}$ The forum state is not to be bound by the foreign state's resolution of the interests of secrecy and of ascertainment of truth in the foreign state's courts. Where, on the other hand, as in the problem at hand, the trial and the claim of privilege are to be heard by different courts, the factors of residence, place of communication, and locus of the confidential relation-i.e., the place where or in reference to which the transactions establishing the relation took place- become increasingly important.

Where the deponent claims a privilege under local law which is not recognized in the state where the action is pending, several conflicting observations are pertinent. On the one hand if the legislature has said that a witness "shall not be required [to testify] by any court," judicial processes of the state (and, under Erie, of the federal courts sitting within the state) should not be used to compel disclosure regardless of whether the courts are independently trying an issue of fact or are lending their jurisdiction in aid of the courts of a sister state. ${ }^{59}$ Moreover, if a state legislature has made the compulsory process of its courts available to litigants in foreign courts it can hardly be presumed to have "intended to permit greater latitude in the examination of [its] citizens in cases originating without, than within, [the] jurisdiction." 60

Although such observations suggest that a privilege recognized only by the deposition state should be applied, there may be circumstances under which its enforcement would be unjustified and might also constitute an extraterritorial application of the deposition state's law in violation of constitutional due process, ${ }^{61}$ and, in some cases, be an unconstitutional denial of full faith and credit

${ }^{57}$ Societe Internationale v. McGrath, 9 F.R.D. 680 (D.D.C., 1950); In re Katz' Estate, 192 Misc. 416, 81 N.Y.S. 2d 21 (Surr. Ct., 1948); Wexler v. Metropolitan Life Ins. Co., 38 N.Y.S. 2d 889 (City Ct. N.Y., 1942); Doll v. Equitable Life Assur. Soc., 138 Fed. 705 (C.A. 3d, 1905); 15 C.J.S. Conflict of Laws $\$ 22 \mathrm{j}(1939)$. But compare Levy v. Mutual Life Ins. Co., 56 N.Y.S. 2d 32 (S. Ct., 1945). The New York trial court allowed a commission to issue for taking the depositions of Georgia physicians. The court, while mentioning the absence of any privilege in Georgia, appeared to rely on the validity under Georgia law of a waiver of privilege contained in the policy, but it is unclear whether the waiver might not also have been valid under the New York decisions to waive the physician-patient privilege of that state.

${ }^{58}$ This is the language of the Illinois public accountants privilege statute. See note 7 supra. Compare the Alabama newsmen's statute, note 15 supra.

${ }^{60}$ This apparently was the position of the court in Palmer v. Fisher, 228 F. 2d 603, 608 (C.A. 7th, 1955). Consult text p. 705 supra.

${ }^{60}$ In re Denning, 44 Del. 470, 474, 61 A. 2d 657, 659 (Super. Ct., 1948). The difficulty with this argument is that it assumes the witness to be a "citizen" of the deposition state.

${ }^{61}$ Compare Home Ins. Co. v. Dick, 281 U.S. 397 (1930). On the general problem, consult Overton, State Decisions in Conflict of Laws and Review by the United States Supreme Court under the Due-Process Clause, 22 Ore. L. Rev. 109 (1943). Where no conflict-of-laws elements are present state courts have held that enforcing a privilege does not deprive a litigant of due process of law. Yazoo \& M.V.R. Co. v. Decker, 150 Miss. 621, 116 So. 287 (1928); New Orleans \& N.E. R. Co. v. Jackson, 145 Miss. 702, 110 So. 586 (1926). 
to the trial state's law. ${ }^{62}$ The Supreme Court has repeatedly held that state statutes are "Public Acts" within the meaning of the full faith and credit clause, ${ }^{63}$ and $\mathrm{Mr}$. Justice Jackson maintains that the Court has similarly treated state decisional law. ${ }^{64}$ The Court has held, however, that the clause does not require a court to apply foreign law in every case where it is applicable; ${ }^{65}$ if the forum state ${ }^{66}$ is found to have a sufficient interest. in the transaction to outweigh the unifying policy of the full faith and credit clause, ${ }^{67}$ and has announced a clear policy on the matter, it may constitutionally apply its own law rather than that of a sister state. ${ }^{68}$

Where the deposition state is either the place of residence or place of business of the parties to the communication or the place of the communication or the locus of the relationship, the deposition state's interest in the confidential relation would appear sufficient to justify an application of the local law of privilege. But where none of these factors is present, as, for example, where the witness merely happens to be found within the jurisdiction, that state would seem to have no legitimate interest in obstructing the fact-finding processes of the trial state, and if the courts or legislature of the trial state have declared that the privilege will not be recognized, the deposition state could not ignore that declaration without running afoul of the full faith and credit clause. ${ }^{69}$

Even more perplexing is a determination of the appropriate rule where the

62 "A federal court . . . is bound equally with the courts of the State [in which it sits] to observe the command of the full faith and credit clause, where applicable." Bradford Elec. Co. v. Clapper, 286 U.S. 145, 155 (1932).

83 E.g., Alaska Packers Ass'n v. Industrial Accident Comm'n, 294 U.S. 532 (1935); Bradford Elec. Co. v. Clapper, 286 U.S. 145 (1932). Consult Jackson, Full Faith and CreditThe Lawyer's Clause of the Constitution, 45 Col. L. Rev. 1 (1945).

64 Jackson, op. cit. supra note 63, at p. 12. Consult 1 Crosskey, Politics and the Constitution in the History of the United States 541-57 (1953).

65 E.g., Alaska Packers Ass'n v. Industrial Accident Comm'n, 294 U.S. 532 (1935): “[T]he conflict [between the statutes of sister states] is to be resolved, not by giving automatic effect to the full faith and credit clause, compelling the courts of each state to subordinate its own statutes to those of the other, but by appraising the governmental interests of each jurisdiction, and turning the scale of decision according to their weight." Ibid., at 547 .

Be In this context "forum state" refers to the state whose courts are called upon to give faith and credit to foreign law in a proceeding before them.

${ }^{67}$ It seems clear that the balance is to be struck between the policy of the forum state and that of the constitutional provision, rather than between the conflicting policies of the two states. Hughes v. Fetter, 341 U.S. 609 (1951). But see Alaska Packers Ass'n Y. Industrial Accident Comm'n, 294 U.S. 532, 547 (1935), quoted in note 65 supra.

${ }^{8}$ Carroll v. Lanza, 349 U.S. 408 (1955); Pacific Employers Ins. Co. v. Industrial Accident Comm'n, 306 U.S. 493 (1939); Alaska Packers Ass'n v. Industrial Accident Comm'n, 294 U.S. 532 (1935). For a comprehensive review of the decisions consult the dissenting opinion of Frankfurter, J., in Carroll v. Lanza, supra, at 414-20. The "balancing of interests" approach has been critically examined. Jackson, op. cit. supra note 63 . Consult generally 1 Crosskey, op. cit. supra note 64 , at $541-47$.

${ }^{89}$ Where the trial state has neither statute nor judicial decision denying the privilege, but is merely silent, no full faith and credit question is raised. 
deponent claims a privilege granted by the trial state and denied by the deposition state. On the one hand it may be urged, first, that a court will apply its own law unless a good reason is shown for applying the law of some other state; that the trial court could easily have inserted into the commission for taking the out-of-state deposition a restriction limiting the examination to matters not privileged by the laws of the trial state, ${ }^{70}$ and that absent such a restriction, the deposition court is justified in declining to undertake the inconvenience of ascertaining and applying a foreign body of privilege law. Secondly, cases may be cited in which the deposition court has declined to determine the admissibility of evidence sought from the deponent, leaving that question to be decided by the trial court. ${ }^{71}$ The difficulty, however, with using these cases to support the proposition that questions of privilege under trial state law should also be left to the determination of the trial court is the resulting failure to distinguish between the respective policies of non-admissibility and privilege. The former operates to exclude from consideration by the triers of fact evidence that may inflame, confuse or mislead them; the latter is designed to foster policies wholly extrinsic to the particular lawsuit. It is irrelevant that the triers of fact will not hear the evidence since the damage sought to be prevented by the privilege is done when the communicatee is forced to testify (or the person to whom he has divulged his confidence is allowed to testify)..$^{72} \mathrm{~A}$ second difficulty arises because a deposition may be taken for discovery purposes as well as for preserving testimony for introduction at the trial. Privileged matter disclosed at the deposition hearing may lead the party proponent to other, non-privileged, evidence which he would otherwise not have been able to discover. The procedural expedient of allowing a party to take the deposition of a witness who is beyond the process of the trial court should not be allowed to give him an advantage which he would not have had if the witness were within the jurisdiction. Finally, in support of enforcing the privilege it may be urged that since the deposition state has no interest in the ascertainment of truth in the particular litigation, the presence or absence of any of the factors considered above is irrelevant, and that no policy of the deposition state will be thwarted or subordinated by giving effect to the privilege of the trial state.

${ }^{70}$ See, e.g., Wexler v. Metropolitan Life Ins. Co., 38 N.Y.S. 2d 889 (City Ct. N.Y., 1942). A similar procedure is available under Fed. Rules Civ. Proc. 30(b).

7 Consult note 44 supra.

72 See Application of Franklin Washington Trust Co., 148 N.Y.S. 2d 731, 733 (S. Ct., 1956); In re Martin, 141 Ohio St. 87, 101, 47 N.E. 2d 388, 395 (1943); In re Whitlock, 51 Hun 351, 354,3 N.Y. Supp. 855,857 (S. Ct., 1889). Rule 26(b), while restricting examination to matters "not privileged," provides that inadmissibility at the trial is not ground for objection at the deposition hearing. Fed. Rules Civ. Proc. 26(b).

A closer examination of the particular policies behind different privileges may reveal that, for some, exclusion at the trial is, in fact, sufficient protection to serve their purpose. Such an inquiry is beyond the scope of this comment, but it may be noted that Rule 26(b) protects privileged matters from disclosure at the deposition stage without regard for the particular privilege involved. 
On balance, it would appear that any inconvenience in applying the foreign law is outweighed by the possibility of an unwarranted windfall to one of the litigants. Regardless of its interest in the relationship, the deposition state should apply a privilege claimed under the laws of the trial state. Indeed, notwithstanding the deposition state's "interest" in the relationship, the lack of any strong policy which would be thwarted by respecting the claim of privilege leads to the conclusion that a refusal to honor the foreign law of privilege would violate the full faith and credit clause..$^{73}$ To justify a failure to give full faith and credit to the law of a sister state, interest in the transaction is not sufficient; there must also be some declaration of public policy contrary to the foreign law for which faith and credit is claimed. ${ }^{74}$

With the exception, then, of the situation in which a local privilege is claimed by parties to a relationship having no connection with the deposition state, the appropriate law to be applied by a state court is the law, whether of the trial or deposition state, which grants the privilege. This is also the appropriate law to be applied in a federal court proceeding under Rule 26 unless, in a situation where the deposition state is not bound by the full faith and credit clause, a contrary state rule has been announced. In such a case Klaxon Co. v. Stentor Co. would appear to require application of whatever privilege law would be applied by the state court. Only by adopting Professor Green's construction of Rule 43(a), with its risk of constitutional difficulties raised by the Erie decision, could a federal court avoid the necessity for any reference to state law. The risk, however, is probably worth taking. The advantages to be gained by freeing the federal courts from the compulsion to enforce state-created privileges, many of which are of questionable value, would seem greatly to outweigh the possibility that, under Erie, the Constitution might be held to preclude Congress from determining (or authorizing the courts to determine) the restrictions to be placed on developing the facts of diversity litigation.

73 This discussion has assumed that the full faith and credit clause may be applicable to "procedural" statutes. Without examining the merits of this assumption generally, it may be suggested that where any state interest other than the smooth administration of justice is involved the clause should apply. Accordingly, privilege statutes should be a proper object of that clause.

74 See Hughes v. Fetter, 341 U.S. 609 (1951). 